\title{
Studies towards a biomimetic synthesis of $\alpha$-cyclopiazonic acid: synthesis of 5-substituted isoxazole-4-carboxylic esters
}

\author{
Vijayalakshmi A. Moorthie, ${ }^{a, \dagger}$ Eoghan M. McGarrigle, ${ }^{a}$ Rachel Stenson, ${ }^{b}$ and \\ Varinder K. Aggarwal ${ }^{\mathrm{a}, *}$ \\ ${ }^{a}$ School of Chemistry, Cantock's Close, Bristol BS8 1TS, England \\ ${ }^{b}$ Syngenta, PO Box A38, Leeds Rd, Huddersfield, W. Yorks. HD2 IFF, England \\ E-mail:V.Aggarwal@bristol.ac.uk
}

\section{Dedicated to Prof. Tietze on the occasion of his 65 th birthday}

\begin{abstract}
An efficient, high yielding synthesis of ethyl 5-hydroxymethyl-3-methylisoxazole-4-carboxylate has been developed, based on a procedure by Gelin which involves reaction of ethyl acetoacetate with chloroacetyl chloride followed by treatment with hydroxylamine hydrochloride. The product of this reaction was then converted into the bromide and reacted with tetrahydrothiophene to give sulfonium salts in up to $71 \%$ overall yield (from ethyl acetoacetate). The synthesis is suitable for use with a chiral sulfide and for large-scale use. The synthesis of ethyl 5-formyl-3-methyl-4-isoxazolecarboxylate and the corresponding tosylhydrazone are also reported. These isoxazoles are starting materials for a proposed convergent, biomimetic synthesis of $\alpha$-cyclopiazonic acid.
\end{abstract}

Keywords: $\alpha$-Cyclopiazonic Acid, sulfur ylide, isoxazole, sulfonium salt

\section{Introduction}

$\alpha$-Cyclopiazonic acid (1) is a mycotoxic metabolite produced by Penicilum cyclopium Westling. ${ }^{1,2}$ It has a range of biological effects, most notably $\mathrm{Ca}^{2+}$-ATPase inhibition, and can be used as tool for the elucidation of intracellular $\mathrm{Ca}^{2+}$ influx. ${ }^{3-5} \alpha$-Cyclopiazonic acid is currently synthesized using fermentation, but a chemical synthesis would allow variation of the structure in a controlled way. The biological activity and structural complexity of $\mathbf{1}$ make it an attractive and challenging target for total synthesis. Since its isolation and characterization in 1968 by Holzapfel $^{1,6,7}$ three racemic syntheses of $\alpha$-cyclopiazonic acid have been reported by the groups

\footnotetext{
${ }^{\dagger}$ Present address: Department of Chemistry, University of Alberta, Edmonton, Alberta, Canada T6G 2G2
} 
of Kozikowski, Natsume and Knight, respectively. ${ }^{8-10}$ All three make use of pyrrolidine-2carboxylate 2 as a late-stage intermediate. The most recent synthesis by Hashkins and Knight is the most efficient and uses a high-yielding carbocationic cascade double cyclization to synthesize two of the non-indole rings in its key step. No enantioselective syntheses have been reported to date.

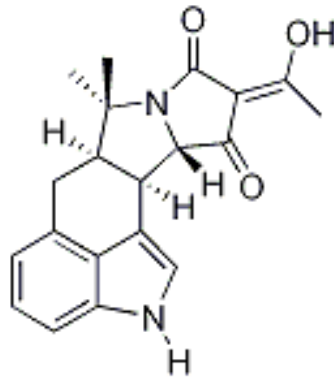

$\alpha$-Cyclopiazonic acid

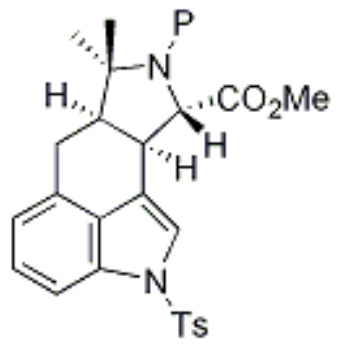

2

We have considered a biomimetic approach to $\mathbf{1}$. It has been shown that tryptophan and $\beta$ cyclopiazonic acid are biosynthetic precursors of $\mathbf{1}$ (Scheme 1). ${ }^{11,12}$ Steyn and his co-workers have established that the 3-pro- $S$-hydrogen atom from tryptophan is lost in the cyclization step and confirmed that the formation of the new C-C bond occurs from the side opposite to the proton removal. $^{13,14}$ However, the mechanism of this oxidative cyclization is not fully understood.

As indicated above, we have engaged in a program to realize a biomimetic enantioselective synthesis of $\alpha$-cyclopiazonic acid. Scheme 2 shows our proposed retrosynthetic plan: the first key step would make use of our asymmetric aziridination methodology to synthesize aziridine 8. ${ }^{15-17}$ This would be followed by a Lewis acid-catalyzed intramolecular cycloaddition of the aziridine to install two of the non-indole rings in one step. ${ }^{18-20}$ The tetramic acid moiety should be accessible by hydrogenolysis of the isoxazole compound $7 .^{21-24}$ The desired aziridine can be disconnected to two combinations of imine and a sulfonium ylide, either $\mathbf{9}$ and $\mathbf{1 0}$ or $\mathbf{1 1}$ and 12. Herein we describe our first steps towards the synthesis of $\alpha$-cyclopiazonic acid - the synthesis of 10 and 12. Although literature precedent suggested that these seemingly 'routine' heterocycles should be accessible in a straightforward manner, we encountered considerable difficulty in making them and so now report a simple, high yielding route to these important intermediates. ${ }^{22}$ 
<smiles>Cn1cc(C[C@@H](N)C(=O)O)c2ccccc21</smiles>

3<smiles>C/C(O)=C1\C(=O)[C@@H]2C3=CNc4cccc(c4[C@H]32)C[C@@H]2C(=O)[C@@H]12</smiles>
$\alpha$-Cyclopiazonic acid

1<smiles>C/C(O)=C1\C(=O)N[C@H](Cc2c[nH]c3ccccc23)C1=O</smiles><smiles>CC(C)=CCc1cccc2c1c(C[C@H]1NC(=O)/C(=C(/C)O)C1=O)cn2[TlH]</smiles>

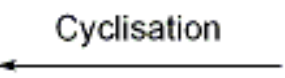

6

Scheme 1. Biosynthesis of $\alpha$-cyclopiazonic acid.<smiles></smiles>

1

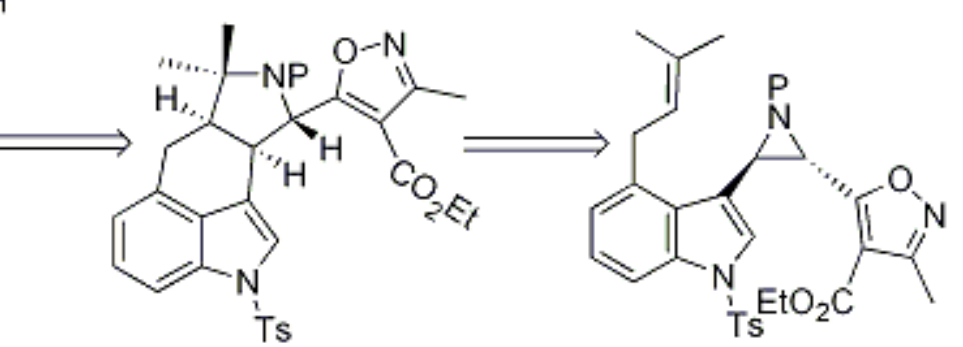

7

8<smiles>CC(C)=CCc1cccc2c1c(C=[NH2+])cn2C(F)(F)F</smiles>

9<smiles>[R]OC(=O)c1c(C)noc1C[Sb](C)(C)C</smiles>

10<smiles>CC(C)=CCc1cccc2c1c(C=[Se])cn2C(F)(F)F</smiles>

11<smiles>CCOC(=O)c1c(C)noc1/C=N\P</smiles>

12

Scheme 2. Retrosynthetic analysis of $\alpha$-cyclopiazonic acid. 


\section{Results and Discussion}

Functionalized isoxazoles $\mathbf{1 0 / 1 2}$ can be disconnected in a number of ways as indicated in Scheme 3. We initially focused on disconnection a since bromination of isoxazole $\mathbf{1 3}$ had been reported. ${ }^{21}$ We also anticipated that isoxazole $\mathbf{1 3}$ might be a common precursor for the synthesis of 10 and 12.

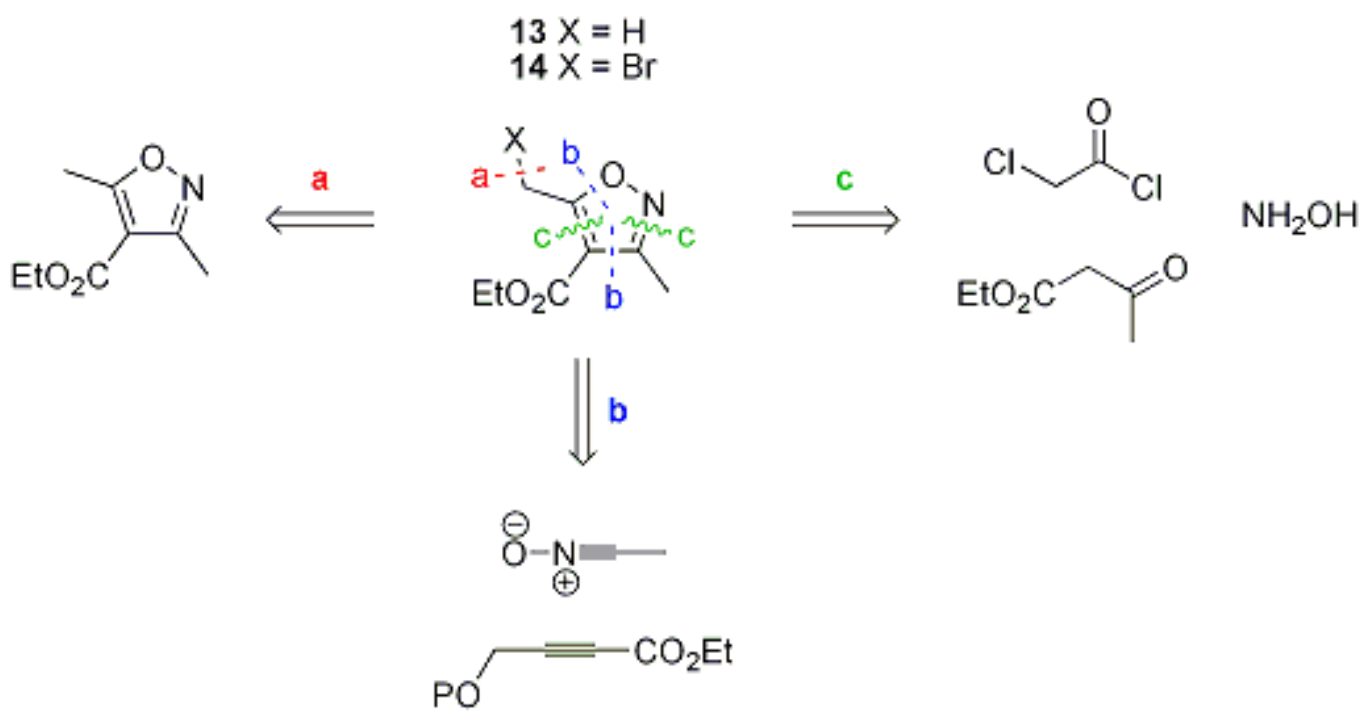

Scheme 3. Retrosynthetic analysis of isoxazoles.

3,5-Disubstituted isoxazole-4-carboxylates can be accessed by the cycloaddition of nitrile oxides with suitable dipolarophiles. Following the procedure of Jones, ${ }^{21,25}$ the pyrrolidine enamine of ethyl acetoacetate was reacted with acetonitrile $N$-oxide (generated in situ) to yield 3,5-dimethyl isoxazole $\mathbf{1 3}$ in $43 \%$ (Scheme 4) ${ }^{26}$ Bromination of the C-5-methyl group was achieved in $64 \%$ yield using NBS and photolytic initiation ${ }^{21,27}$ but this material was contaminated with both starting material and the C3-isomer 15. Batra and co-workers encountered related selectivity issues in their attempts to brominate ethyl 3-aryl-5methylisoxazole-4-carboxylates. ${ }^{28}$ Column chromatography of the mixture of 14:13:15 (87:12:1 ratio) led to some decomposition of the bromide rendering this synthesis rather inefficient.

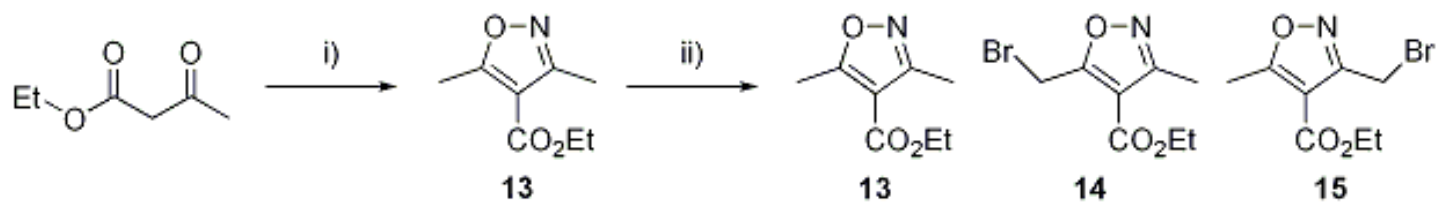

Scheme 4. Synthesis and bromination of 3,5-dimethyl isoxazole 13. Reagents and conditions: (i) Pyrrolidine (1.3 eq.), $\mathrm{EtNO}_{2}$ (1.3 eq.), $\mathrm{Et}_{3} \mathrm{~N}$ (2.6 eq.), $\mathrm{POCl}_{3}$ (1.3 eq.), benzene, reflux, $3.5 \mathrm{~h}$, 43\%. (ii) 13 (59mM in $\mathrm{CCl}_{4}$ ), NBS (1.3 eq), sun-lamp, 3.5 h. 14:13:15 = 87:12:1. 
In addition, it was found that transformation of either 13 or bromide 14 into aldehyde 16 was more troublesome than expected. Direct oxidation with a variety of oxidizing agents failed (Scheme 5), ${ }^{29,30}$ despite literature precedent for the oxidation of ethyl 3-aryl-5bromomethylisoxazole-4-carboxylates. $^{28}$

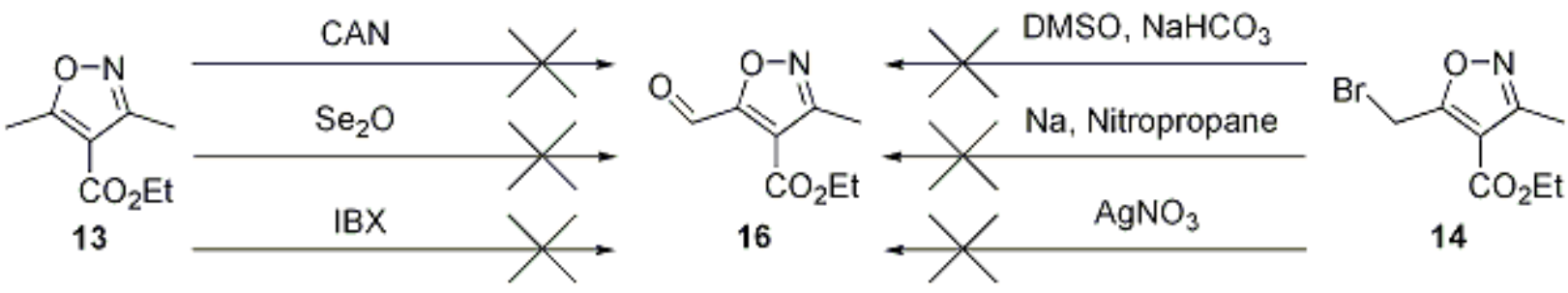

Scheme 5. Attempts at direct oxidation of the bromide and the dimethyl isoxazole.

We therefore required a functionalized 5-methyl group in the product immediately following cycloaddition, and so considered disconnection $\mathbf{b}$. The known alkyne 18 was prepared in two steps from propargyl alcohol. After protecting the alcohol as the THP ether $\mathbf{1 7}$ (Scheme 6), ${ }^{31}$ treatment with $n$-BuLi followed by addition of ethyl chloroformate furnished alkyne $\mathbf{1 8}^{32,33}$ Using the same strategy as for the synthesis of 13, isoxazole 18 was obtained in $50 \%$ yield from the cycloaddition of $\mathbf{1 8}$ with acetonitrile $N$-oxide. However, attempts to separate $\mathbf{1 9}$ from the unreacted precursor 18 failed and after treating the crude mixture with toluenesulfonic acid our attempted separations of $\mathbf{2 1}$ and $\mathbf{2 0}$ were also unsuccessful. We were also unable to push the cycloaddition reaction to completion.

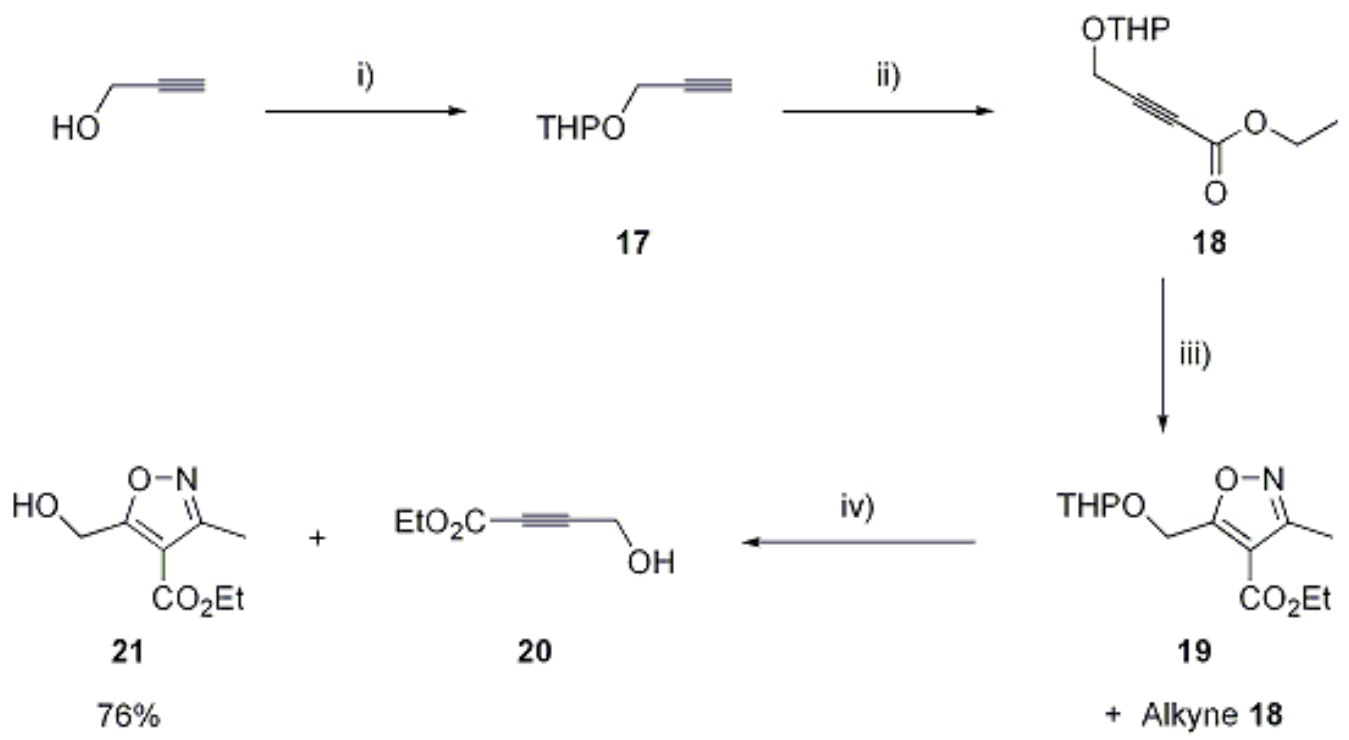

Scheme 6. Reagents and conditions: (i) DHP (1 eq.), $\mathrm{POCl}_{3}$ (1.5 eq.), $51 \%$ (ii) $n$-BuLi ( 1 eq.), $\mathrm{ClCO}_{2} \mathrm{Et}$ (1.4 eq.), $\mathrm{Et}_{2} \mathrm{O}, 37 \%$. (iii) $\mathrm{EtNO}_{2}$ (1.5 eq.), $\mathrm{POCl}_{3}$ (1.5 eq.), 50\%. (iv) $\mathrm{TsOH}$ (cat.), $\mathrm{EtOH}$. 
Finally, the synthesis of alcohol 21 was achieved by modifying a procedure of Gelin and coworkers, ${ }^{34-36}$ to obtain the furanone 22 , and then treating the crude product with hydroxylamine hydrochloride (disconnection c, Scheme 7). We were able to improve significantly on the literature yield of $22(50 \%) .{ }^{34}$ We found that the low yields were due to incomplete reaction of 24b. Therefore, after addition of ethyl chloroformate at $-10{ }^{\circ} \mathrm{C}$, the reaction was allowed to warm to room temperature and was stirred for a further 2 hours. This allowed us to obtain the alcohol 21 in $79 \%$ yield over two steps.
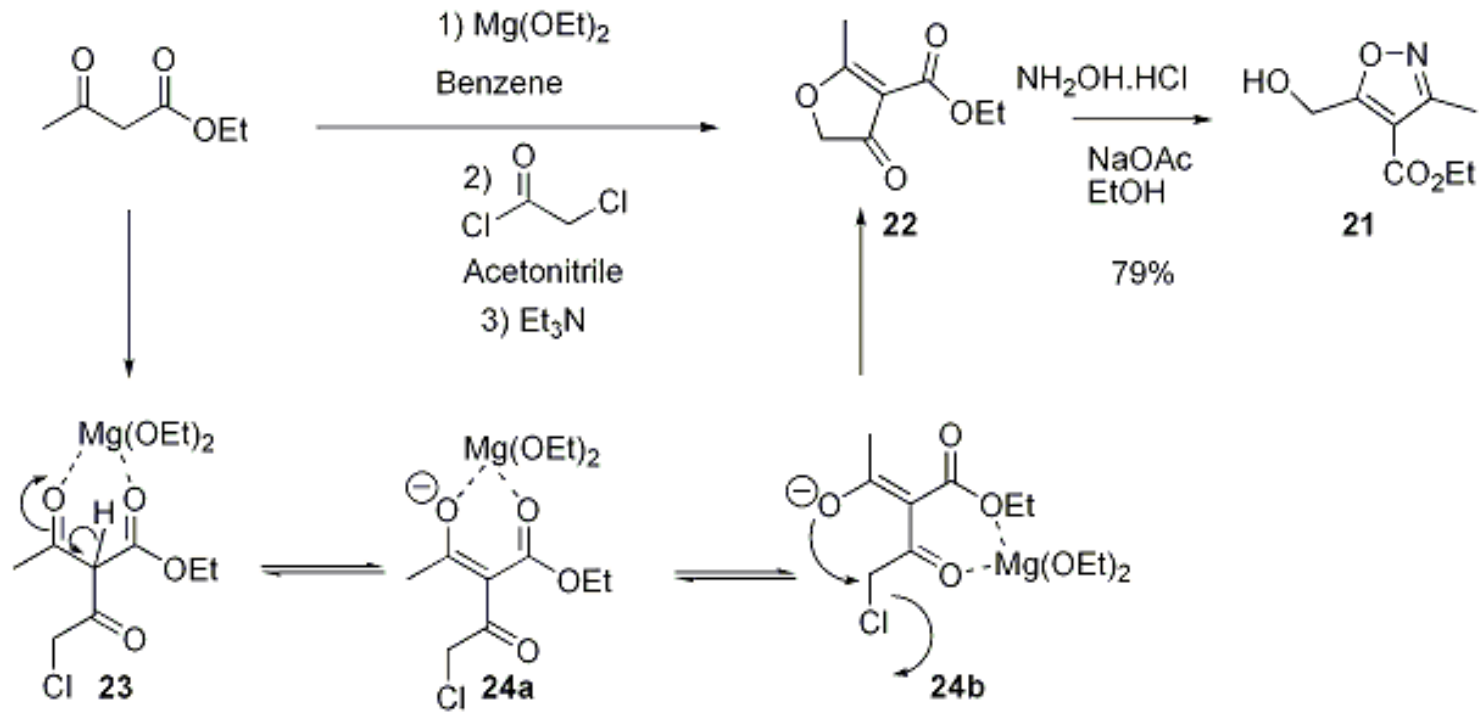

Scheme 7. Synthesis of isoxazole 21 via a furanone.

The isoxazole sulfonium salt $\mathbf{2 7}$ was our next target. In many cases, sulfonium salts can be synthesized directly from the corresponding alcohols by treatment of a suitable mineral acid (e.g., $\mathrm{HBF}_{4}$ or $\mathrm{HPF}_{6}$ ). ${ }^{37,38} \mathrm{~A}$ variety of conditions was tested but the isoxazole 21 was unreactive, probably because it is rather electron-deficient (this reaction works best with electron-rich aromatics). As such, alcohol 21 was first converted into bromide 14. By using $\mathrm{PBr}_{3}$ and $\mathrm{DMF}$ in toluene this transformation occurred in quantitative yield. ${ }^{39}$ The use of DMF was essential to the success of this reaction; the use of $\mathrm{PBr}_{3}$ in the absence of DMF, or indeed other brominating agents, did not lead to any bromination.

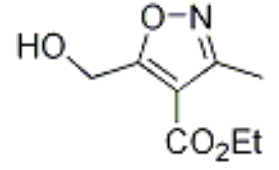

21

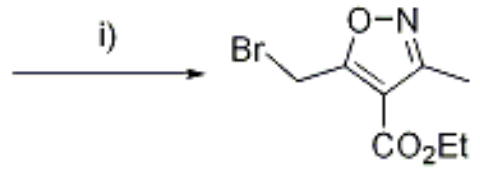

14

Scheme 8. Improved synthesis of bromide 14. Reagents and conditions: $\mathrm{PBr}_{3}$ (1.6 eq.), DMF (1.6 eq.), toluene, reflux, quantitative. 
The bromide 14 was transformed into the sulfonium salt 25a in $61 \%$ yield by treatment with tetrahydrothiophene (THT). The sulfonium bromide has a tendency to revert to starting materials and therefore it was necessary to exchange the counter-ion. After some experimentation (Table 1), it was found that this was best achieved by stirring the bromide in acetone with the appropriate sodium salt. ${ }^{40}$ This procedure furnished sulfonium salts $\mathbf{2 5 b}$-d in yields of 55\%, 65\% and $91 \%$, respectively. Attempts to achieve this salt formation and counter-ion exchange in one pot led to lower yields.

Table 1. Synthesis of isoxazole sulfonium salts<smiles>COC(=O)c1c(CBr)noc1CBr</smiles>

14

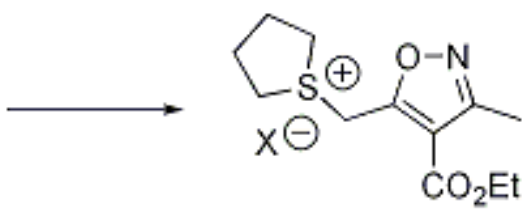

25

\begin{tabular}{cccccc}
\hline Entry & THT equiv. & Time/days & $\mathrm{X}$ & Product & Yield (\%) \\
\hline $1^{\mathrm{a}}$ & 2 & 1 & $\mathrm{Br}$ & $\mathbf{2 5 a}$ & 30 \\
$2^{\mathrm{a}}$ & 5 & 1 & $\mathrm{Br}$ & $\mathbf{2 5 a}$ & 61 \\
$3^{\mathrm{b}}$ & 5 & 2 & $\mathrm{BF}_{4}$ & $\mathbf{2 5 b}$ & 55 \\
$4^{\mathrm{b}}$ & 5 & 1 & $\mathrm{BF}_{4}$ & $\mathbf{2 5 b}$ & $91^{\mathrm{c}}$ \\
$5^{\mathrm{b}}$ & 2 & 2 & $\mathrm{PF}_{6}$ & $\mathbf{2 5 c}$ & 65 \\
$6^{\mathrm{b}}$ & 2 & 2 & $\mathrm{ClO}_{4}$ & $\mathbf{2 5 d}$ & 91 \\
\hline
\end{tabular}

${ }^{a}$ Reagents stirred neat in one pot; ${ }^{b}$ Reagents stirred in one pot in minimum acetone; ${ }^{c} \mathbf{2 5 a}$ treated with $\mathrm{NaBF}_{4}$ in minimum acetone.

The isoxazole hydrazone salt $\mathbf{4 3}$ was our next target. Oxidation of alcohol 21 using PCC ${ }^{35}$ was sluggish (62\% yield after one week). Oxidation using Dess-Martin periodinane (DMP) in dichloromethane gave a similar yield after $15 \mathrm{~min}$, but longer reaction times led to decomposition of the product. After two weeks PCC oxidation gave an $82 \%$ yield of the desired aldehyde 16 (Table 2).

The aldehyde $\mathbf{1 6}$ was treated with tosylhydrazide to give the tosylhydrazone $\mathbf{2 6}$ in $76 \%$ yield (Scheme 9). Treatment of $\mathbf{2 6}$ with sodium methoxide (generated in situ from $\mathrm{Na}$ and $\mathrm{MeOH}$ ) resulted in the tosylhydrazone sodium salt 27 , which underwent decomposition to the diazo compound 28 during work up (even at low temperature). Thus, if our catalytic aziridination methodology was to be employed it would have to be via either the direct addition of the diazo compound or alternatively via the in situ deprotonation of the tosylhydrazone salt using LiHMDS or NaHMDS at low temperature. ${ }^{15,41}$ 
Table 2. Oxidation of alcohol 21 to aldehyde 16

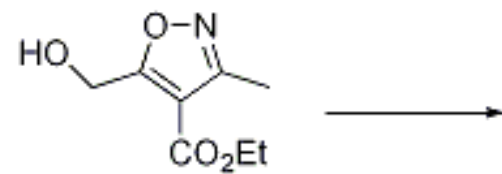

21

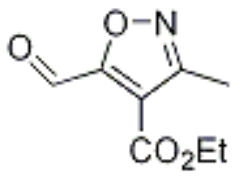

16

\begin{tabular}{cccc}
\hline Entry & Oxidant & Reaction Time & Yield \% \\
\hline 1 & DMP & 15 min & 62 \\
2 & DMP & 30 min & 32 and unknown product \\
3 & PCC & 1 week & 60 \\
4 & PCC & 2 weeks & 82 \\
\hline
\end{tabular}

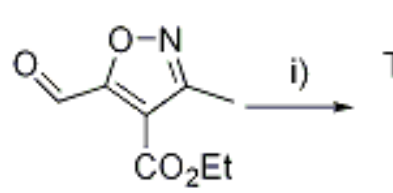

16

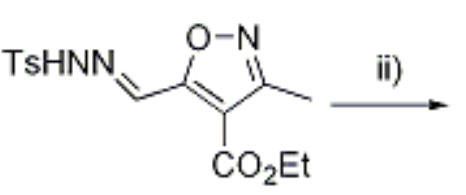

26

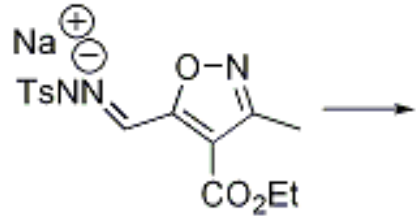

27

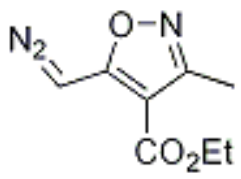

28

Scheme 9. Attempted synthesis of hydrazide 27. Reagents and Conditions: $\mathrm{TsNHNH}_{2}(1.01$ eq.), $\mathrm{MeOH}, 76 \%$; ii) $\mathrm{NaOMe}$ (1.01 eq.), $\mathrm{MeOH}$.

We now have a successful route to the functionalized isoxazoles, which are important and useful precursors for synthesis. Furthermore, we have prepared the corresponding tosylhydrazone and sulfonium salts - substrates for the catalytic and stoichiometric aziridination protocols, respectively. Work on synthesis of the appropriate indole moieties is ongoing and we hope to report a completed synthesis of $\alpha$-cyclopiazonic acid in due course.

\section{Experimental Section}

General Procedures. Anhydrous benzene was obtained from Aldrich. Dried $\mathrm{CH}_{2} \mathrm{Cl}_{2}$ was obtained from the dry solvent dispenser in the University of Bristol, which is built by Anhydrous Engineering, based on the Grubbs design. ${ }^{42}$ Acetonitrile was freshly distilled from calcium hydride. All reagents were either used as received from commercial sources or purified using recognized methods. Reactions requiring anhydrous conditions were performed using oven-dried glassware under an atmosphere of dry nitrogen. TLC was performed on aluminum sheets precoated with silica (60 F254). The plates were developed using standard visualizing agents. Flash column chromatography was performed using silica gel (Merck Silica gel 60 F254, 230-400 mesh). ${ }^{1} \mathrm{H}$ NMR spectra were recorded on Jeol Delta 270 (270 MHz), Delta 400 (400 MHz) or 
ecp $400(400 \mathrm{MHz})$ spectrometers, using dry $\mathrm{CDCl}_{3}$, or $\mathrm{CD}_{3} \mathrm{OD}$ as the solvent. Coupling constants, $J$, are quoted in Hertz $(\mathrm{Hz})$. Chemical shifts $(\delta)$ are quoted in parts per million (ppm) and are relative to tetramethylsilane $(\delta=0 \mathrm{ppm})$ as the internal standard in $\mathrm{CDCl}_{3}$ or the residual solvent peak in $\mathrm{CD}_{3} \mathrm{OD}(\delta=3.42 \mathrm{ppm}) .{ }^{13} \mathrm{C}$ NMR spectra were recorded on a Delta 400 (100 $\mathrm{MHz})$ or ecp $400(100 \mathrm{MHz})$ spectrometer. Melting points were measured on a Köfler Hot stage Micro Melting point apparatus and are uncorrected. Elemental analyses were performed on a Carlo Erba EA1108 or a Perkin Elmer 2400 CHN elemental analyzer. Samples for infra red spectroscopy were prepared using the neat product and the spectra recorded using a PerkinElmer $157 \mathrm{G}$ FT-IR spectrometer. Only characteristic absorbencies $\left(v_{\max }\right)$ are reported in $\mathrm{cm}^{-1}$. Both low- and high-resolution mass spectra $(\mathrm{m} / \mathrm{z})$ were recorded with a Fisons/VG Analytic Autospec System, with only molecular ions $\left([\mathrm{M}]^{+}\right.$or $\left.[\mathrm{M}+\mathrm{H}]^{+}\right)$and major peaks being reported with intensities quoted as percentages of the base peak. GCMS retention times $\left(\mathrm{R}_{\mathrm{t}}\right)$ and low resolution MS were recorded on an Agilent 6890 GC (column: HP190915-433 HP-5MS 5\% Phenyl Methyl Siloxane; capillary $30 \mathrm{~m} \times 250 \mu \mathrm{m} \times 0.25 \mu \mathrm{m}$ nominal; carrier gas: helium 1 $\mathrm{mL} / \mathrm{min}$ (constant flow mode); injector: $250{ }^{\circ} \mathrm{C}$ (splitless mode). Mass spec. detector: Agilent MSD 5973 (EI mode); oven: $70{ }^{\circ} \mathrm{C}(3 \mathrm{~min}), 15^{\circ} \mathrm{C} / \mathrm{min}(15.3 \mathrm{~min}), 300{ }^{\circ} \mathrm{C}(8 \mathrm{~min})$.

Ethyl 2-methyl-4-oxo-4,5-dihydro-3-furancarboxylate (22). ${ }^{34,43}$ The furanone 22 was prepared following a modified literature procedure. ${ }^{34,43}$ Ethyl acetoacetate $(5.01 \mathrm{~g}, 38.5 \mathrm{~mol})$ was added to a suspension of magnesium ethoxide $(6.04 \mathrm{~g}, 42.3 \mathrm{~mol})$ in anhydrous benzene $(9 \mathrm{~mL})$, the mixture was stirred for one hour at room temperature. Anhydrous acetonitrile $(9 \mathrm{~mL})$ was added to the reaction mixture and the flask was cooled to $-10{ }^{\circ} \mathrm{C}$, followed by the slow addition of $\alpha$ chloroacetyl chloride $(3.32 \mathrm{~mL}, 38.5 \mathrm{~mol})$, after which the mixture was allowed to warm to room temperature and left to stir for two hours. A dilute solution of sulfuric acid ( $1 \mathrm{~mL}$ acid in $35 \mathrm{~mL}$ ice/water) was added, followed by extraction with diethyl ether. The combined organic fractions were dried over $\mathrm{MgSO}_{4}$ and filtered, the filtrate was then cooled to $0{ }^{\circ} \mathrm{C}$ and a solution of triethylamine $(5.4 \mathrm{~mL})$ in diethyl ether $(3 \mathrm{~mL})$ added. The reaction mixture was left to stir at room temperature overnight. The precipitated triethylamine hydrochloride salt was filtered off and the diethyl ether evaporated under vacuum to yield a yellow gum ( $6.09 \mathrm{~g}, 93 \%$ crude yield). A small amount was recrystallized from diethyl ether which yielded a white solid for characterization; mp 76.5-77.5 ${ }^{\circ} \mathrm{C}\left(\mathrm{Et}_{2} \mathrm{O}\right) ; \mathrm{R}_{f} 0.5$ (EtOAc/Petroleum ether, 2:3); ${ }^{1} \mathrm{H}$ NMR (400 $\left.\mathrm{MHz}, \mathrm{CDCl}_{3}\right) \delta_{\mathrm{H}} 1.39\left(3 \mathrm{H}, \mathrm{t}, J=6.84, \mathrm{CO}_{2} \mathrm{CH}_{2} \mathrm{CH}_{3}\right), 2.45\left(3 \mathrm{H}, \mathrm{s}, H_{3} \mathrm{CC}=\mathrm{C}\right), 4.37(2 \mathrm{H}, \mathrm{q}, J=$ 6.84, $\left.\mathrm{CO}_{2} \mathrm{CH}_{2} \mathrm{Me}\right), 4.91\left(2 \mathrm{H}, \mathrm{s}, \mathrm{OCH}_{2} \mathrm{C}=\mathrm{O}\right) ;{ }^{13} \mathrm{C}\left(100 \mathrm{MHz}, \mathrm{CDCl}_{3}\right) \delta_{\mathrm{C}} 199.0\left(4^{\circ} \mathrm{C}\right), 196.0\left(4^{\circ}\right.$ C), $162.3\left(4^{\circ} \mathrm{C}\right), 110.0\left(4^{\circ} \mathrm{C}\right), 75.7\left(\mathrm{CH}_{2}\right), 60.6\left(\mathrm{CH}_{2}\right), 17.8\left(\mathrm{CH}_{3}\right), 14.3\left(\mathrm{CH}_{3}\right)$.

Ethyl 5-(hydroxymethyl)-3-methyl-4-isoxazolecarboxylate (21). ${ }^{44}$ A solution of the furanone 22 (3.00 g, $17.6 \mathrm{mmol}), \mathrm{NaOAc}(1.44 \mathrm{~g}, 17.6 \mathrm{mmol})$ and hydroxylamine hydrochloride (1.22 g, $17.6 \mathrm{mmol})$ in ethanol $(16 \mathrm{~mL})$ was refluxed for an hour. The ethanol was then evaporated under vacuum and the resulting residue was diluted with water $(30 \mathrm{~mL})$. The aqueous mixture was extracted with diethyl ether and the combined organic fractions were washed with brine, dried over $\mathrm{MgSO}_{4}$ and concentrated to give a red oil. The crude oil was subjected to column 
chromatography with $20-0 \%$ petroleum: $\mathrm{Et}_{2} \mathrm{O}$ to give a clear oil, which crystallized overnight to give 21 as a white waxy solid $(2.77 \mathrm{~g}, 85 \%)$; mp 35.5-36.5 ${ }^{\circ} \mathrm{C}$ (Et $2 \mathrm{O}$-hexane) [lit. ${ }^{36} 37{ }^{\circ} \mathrm{C}$ (water)]; $\mathrm{R}_{f} 0.58\left(\mathrm{Et}_{2} \mathrm{O}\right) ;{ }^{1} \mathrm{H}$ NMR $\left(400 \mathrm{MHz}, \mathrm{CDCl}_{3}\right) \delta_{\mathrm{H}} 1.4\left(3 \mathrm{H}, \mathrm{t}, J=6.8, \mathrm{CO}_{2} \mathrm{CH}_{2} \mathrm{CH}_{3}\right), 2.45$ $\left(3 \mathrm{H}, \mathrm{s}, \mathrm{H}_{3} \mathrm{C}-\mathrm{C}=\mathrm{N}\right), 3.93\left(1 \mathrm{H}, \mathrm{bs}, \mathrm{CH}_{2} \mathrm{OH}\right), 4.38\left(2 \mathrm{H}, \mathrm{q}, J=6.8, \mathrm{CO}_{2} \mathrm{CH}_{2} \mathrm{Me}\right), 4.87(2 \mathrm{H}, \mathrm{s}$, $\left.\mathrm{HOCH}_{2} \mathrm{C}\right) ;{ }^{13} \mathrm{C}\left(100 \mathrm{MHz}, \mathrm{CDCl}_{3}\right) \delta_{\mathrm{C}} 177.3\left(4^{\circ} \mathrm{C}\right), 163.3\left(4^{\circ} \mathrm{C}\right), 159.6\left(4^{\circ} \mathrm{C}\right), 109.9\left(4^{\circ} \mathrm{C}\right)$, $61.6\left(\mathrm{CH}_{2}\right), 56.8\left(\mathrm{CH}_{2}\right), 14.20\left(\mathrm{CH}_{3}\right), 11.7\left(\mathrm{CH}_{3}\right)$.

Ethyl 5-(bromomethyl)-3-methyl-4-isoxazolecarboxylate (14). ${ }^{21,27}$ A solution alcohol 21 (1.00 g, $5.40 \mathrm{mmol})$, DMF (0.67 mL, $8.7 \mathrm{mmol})$, and $\mathrm{PBr}_{3}(2.34 \mathrm{~mL}, 8.64 \mathrm{mmol})$ in toluene $(15 \mathrm{~mL})$ was refluxed for one hour. The reaction mixture was cooled to room temperature and washed with water and brine then dried over $\mathrm{MgSO}_{4}$ and concentrated under vacuum to give the bromide as a yellow oil $(1.35 \mathrm{~g}, 100 \%)$. The bromide was used without further purification; $\mathrm{R}_{f} 0.63$ (EtOAc/petroleum, 2:8); ${ }^{1} \mathrm{H}$ NMR $\left(400 \mathrm{MHz}, \mathrm{CD}_{3} \mathrm{OD}\right) \delta_{\mathrm{H}} 1.41\left(3 \mathrm{H}, \mathrm{t}, J=7.8, \mathrm{CO}_{2} \mathrm{CH}_{2} \mathrm{CH}_{3}\right)$, $2.47\left(3 \mathrm{H}, \mathrm{s}, \mathrm{H}_{3} \mathrm{C}-\mathrm{C}=\mathrm{N}\right), 4.38\left(2 \mathrm{H}, \mathrm{q}, J=7.8, \mathrm{CO}_{2} \mathrm{CH}_{2} \mathrm{Me}\right), 4.74\left(2 \mathrm{H}, \mathrm{s}, \mathrm{CH}_{2} \mathrm{Br}\right) ;{ }^{13} \mathrm{C}(100 \mathrm{MHz}$, $\left.\mathrm{CDCl}_{3}\right) \delta_{\mathrm{C}} 171.7\left(4^{\circ} \mathrm{C}\right), 161.3\left(4^{\circ} \mathrm{C}\right), 160.2\left(4^{\circ} \mathrm{C}\right), 109.7\left(4^{\circ} \mathrm{C}\right), 61.2\left(\mathrm{CH}_{2}\right), 17.7\left(\mathrm{CH}_{2}\right), 14.21$ $\left(\mathrm{CH}_{3}\right), 11.8\left(\mathrm{CH}_{3}\right)$; GCMS (EI) $\mathrm{m} / z 247\left(\mathrm{M}^{+}\right) ; \mathrm{R}_{t} 10.6 \mathrm{~min}$.

\section{1-\{[4-(Ethoxycarbonyl)-3-methyl-5-isoxazolyl]methyl\}tetrahydrothiophenium}

tetrafluoroborate (25b). A neat mixture of $14(200 \mathrm{mg}, 0.806 \mathrm{mmol})$ and tetrahydrothiophene (321 mg, $3.64 \mathrm{mmol}$ ) were stirred together for 24 hours at room temperature after which the resulting precipitate was filtered and washed with diethyl ether to yield the isoxazole tetrahydrothiophenium bromide as a white solid. This was added to a solution of sodium tetrafluoroborate $(66 \mathrm{mg}, 0.60 \mathrm{mmol})$ in acetone $(2 \mathrm{~mL})$. The mixture was stirred for a further 24 $\mathrm{h}$ at room temperature. The mixture was filtered and the filtrate evaporated to give the sulfonium salt 25b as a white solid (150 mg, 55\%); mp $112-115{ }^{\circ} \mathrm{C}$ (from $\mathrm{Et}_{2} \mathrm{O} / \mathrm{CH}_{2} \mathrm{Cl}_{2}$ ); $\mathrm{R}_{f} 0.41$ $\left(\mathrm{MeOH} / \mathrm{CH}_{2} \mathrm{Cl}_{2}, 0.5: 9.5\right)$; IR $v_{\max }$ (neat)/ $\mathrm{cm}^{-1} 1725,1610,1292,1020 ;{ }^{1} \mathrm{H}$ NMR $(400 \mathrm{MHz}$, $\left.\mathrm{CD}_{3} \mathrm{OD}\right) \delta_{\mathrm{H}} 1.42\left(3 \mathrm{H}, \mathrm{t}, J=7, \mathrm{CO}_{2} \mathrm{CH}_{2} \mathrm{CH}_{3}\right), 2.40\left(4 \mathrm{H}, \mathrm{m}, 2 \times \mathrm{CH}_{2} \mathrm{CH}_{2} \mathrm{~S}\right), 2.53\left(3 \mathrm{H}, \mathrm{s}, \mathrm{H}_{3} \mathrm{C}-\right.$ $\mathrm{C}=\mathrm{N}), 3.65-3.75\left(4 \mathrm{H}, \mathrm{m}, 2 \times \mathrm{CH}_{2} \mathrm{CH}_{2} \mathrm{~S}\right), 4.42\left(2 \mathrm{H}, \mathrm{q}, J=7, \mathrm{CO}_{2} \mathrm{CH}_{2} \mathrm{CH}_{3}\right), 5.0(2 \mathrm{H}, \mathrm{s}$, $\left.\mathrm{SCH}_{2} \mathrm{C}(\mathrm{O}) \mathrm{C}\right) ;{ }^{13} \mathrm{C} \mathrm{NMR}\left(100 \mathrm{MHz}, \mathrm{CD}_{3} \mathrm{OD}\right) \delta_{\mathrm{C}} 166.18(\mathrm{~s}), 160.8(\mathrm{~s}), 160.2(\mathrm{~s}), 112.6(\mathrm{~s}), 61.3$ (t), $44.0(\mathrm{t}), 34.9(\mathrm{t}, 2 \times \mathrm{C}), 28.4(\mathrm{t}, 2 \times \mathrm{C}), 13.8(\mathrm{q}), 11.1(\mathrm{q}) ; \mathrm{MS}(+\mathrm{ESI}) \mathrm{m} / z 344\left([\mathrm{MH}]^{+}, 7\right), 256$ (100), 85 (13); HRMS: found [M-BF $]^{+}$256.0002, requires $\mathrm{C}_{12} \mathrm{H}_{18} \mathrm{NO}_{3} \mathrm{~S}\left[\mathrm{M}-\mathrm{BF}_{4}\right]^{+}, 256.0007$.

1-\{[4-(Ethoxycarbonyl)-3-methyl-5-isoxazolyl]methyl\}tetrahydrothiophenium perchlorate (25d). Bromide $14(2.00 \mathrm{~g}, 8.06 \mathrm{mmol})$, tetrahydrothiophene $(1.29 \mathrm{~g}, 14.6 \mathrm{mmol})$ and sodium perchlorate $(1.10 \mathrm{~g} 8.98 \mathrm{mmol})$ were stirred in acetone $(5 \mathrm{~mL})$ for 2 days, after which the mixture was filtered and the filtrate concentrated to give a cream solid. Recrystallization from $\mathrm{MeOH}$ and $\mathrm{Et}_{2} \mathrm{O}$ yielded $25 \mathrm{~d}$ as a white solid (2.62 $\mathrm{mg}, 91 \%$ ); mp $113-115{ }^{\circ} \mathrm{C}$ (from $\mathrm{Et}_{2} \mathrm{O}$ ); $\mathrm{R}_{f} 0.5$ $\left(\mathrm{MeOH} / \mathrm{CH}_{2} \mathrm{Cl}_{2}, 0.8: 9.2\right)$; IR $v_{\max }$. (neat)/ $\mathrm{cm}^{-1} 1721,1609,1063 ;{ }^{1} \mathrm{H} \mathrm{NMR}\left(400 \mathrm{MHz}, \mathrm{CD}_{3} \mathrm{OD}\right)$ $\delta_{\mathrm{H}} 1.41\left(3 \mathrm{H}, \mathrm{t}, J=6.8, \mathrm{CO}_{2} \mathrm{CH}_{2} \mathrm{CH}_{3}\right), 2.37\left(2 \mathrm{H}, \mathrm{m}, \mathrm{CH}_{2} \mathrm{CH}_{2} \mathrm{~S}\right), 2.46\left(2 \mathrm{H}, \mathrm{m}, \mathrm{CH}_{2} \mathrm{CH}_{2} \mathrm{~S}\right), 2.50$ $\left(3 \mathrm{H}, \mathrm{s}, \mathrm{H}_{3} \mathrm{C}-\mathrm{C}=\mathrm{N}\right), 3.69\left(2 \mathrm{H}, \mathrm{m}, \mathrm{CH}_{2} \mathrm{CH}_{2} \mathrm{~S}\right), 3.91\left(2 \mathrm{H}, \mathrm{m}, \mathrm{CH}_{2} \mathrm{CH}_{2} \mathrm{~S}\right), 4.43(2 \mathrm{H}, \mathrm{q}, J=6.8$, $\left.\mathrm{CO}_{2} \mathrm{CH}_{2} \mathrm{CH}_{3}\right), 5.02\left(2 \mathrm{H}, \mathrm{s}, \mathrm{SCH}_{2} \mathrm{C}(\mathrm{O}) \mathrm{C}\right) ;{ }^{13} \mathrm{C}\left(100 \mathrm{MHz}, \mathrm{CD}_{3} \mathrm{OD}\right) \delta_{\mathrm{C}} 164.0(\mathrm{~s}), 160.2(\mathrm{~s}), 159.9$ (s), $113.0(\mathrm{~s}), 61.4(\mathrm{t}), 44.2(\mathrm{t}), 29.3(\mathrm{t}, 2 \times \mathrm{C}), 28.9$ (t, $2 \times \mathrm{C}), 13.4$ (q), $11.0(\mathrm{q}) ; \mathrm{MS} \mathrm{m} / z$ (EI) 355 
$\left(\mathrm{M}^{+}, 43\right), 281$ (34), 221 (34), 84 (100); Anal. Calcd for $\mathrm{C}_{12} \mathrm{H}_{18} \mathrm{ClNO}_{7} \mathrm{~S}$ : found $\mathrm{C}, 40.40$; H, 4.98; $\mathrm{N}, 3.74$; requires $\mathrm{C}, 40.51 ; \mathrm{H}, 5.10 ; \mathrm{N}, 3.94$.

\section{1-\{[4-(Ethoxycarbonyl)-3-methyl-5-isoxazolyl]methyl $\}$ tetrahydrothiophenium}

hexafluorophosphate (25c). Bromide $14(0.600 \mathrm{~g}, 2.42 \mathrm{mmol})$, tetrahydrothiophene $(0.441 \mathrm{~g}$, $5.00 \mathrm{mmol})$ and sodium hexafluorophosphate $(0.450 \mathrm{~g}, 2.68 \mathrm{mmol})$ were stirred in acetone $(2$ $\mathrm{mL}$ ) for 2 days, after which the mixture was filtered and the filtrate concentrated to give a brown amorphous solid. Recrystallization from $\mathrm{MeOH}$ yielded a beige amorphous solid $(0.630 \mathrm{mg}$, 65\%); mp 120-124 ${ }^{\circ} \mathrm{C}$ (from $\left.\mathrm{Et}_{2} \mathrm{O} / \mathrm{CH}_{2} \mathrm{Cl}_{2}\right) ; \mathrm{R}_{f} 0.5\left(\mathrm{MeOH} / \mathrm{CH}_{2} \mathrm{Cl}_{2}, 0.8: 9.2\right)$; IR $v_{\max }$ (neat)/ $\mathrm{cm}^{-1}$ 1702, 1623, 1314, 821, 734; ${ }^{1} \mathrm{H}$ NMR (400 MHz, acetone- $\left.\mathrm{d}_{6}\right) \delta_{\mathrm{H}} 1.36(3 \mathrm{H}, \mathrm{t}, J=7.1$, $\left.\mathrm{CO}_{2} \mathrm{CH}_{2} \mathrm{CH}_{3}\right), 2.43\left(3 \mathrm{H}, \mathrm{s}, \mathrm{H}_{3} \mathrm{C}-\mathrm{C}=\mathrm{N}\right), 2.50\left(4 \mathrm{H}, \mathrm{m}, \mathrm{CH}_{2} \mathrm{CH}_{2} \mathrm{~S}\right), 3.89\left(4 \mathrm{H}, \mathrm{m}, \mathrm{CH}_{2} \mathrm{CH}_{2} \mathrm{~S}\right), 4.49$ $\left(2 \mathrm{H}, \mathrm{q}, J=7.1, \mathrm{CO}_{2} \mathrm{CH}_{2} \mathrm{CH}_{3}\right), 5.19\left(2 \mathrm{H}, \mathrm{s}, \mathrm{SCH}_{2} \mathrm{C}(\mathrm{O}) \mathrm{C}\right) ;{ }^{13} \mathrm{C}\left(100 \mathrm{MHz}\right.$, acetone- $\left.\mathrm{d}_{6}\right) \delta_{\mathrm{C}} 165.6$ $(\mathrm{s}), 161.3(\mathrm{~s}), 160.6(\mathrm{~s}), 113.6(\mathrm{~s}), 61.8(\mathrm{t}), 45.0(\mathrm{t}), 36.0(\mathrm{t}, 2 \times \mathrm{C}), 29.0(\mathrm{t}, 2 \times \mathrm{C}), 13.7(\mathrm{q}), 11.1$ (q). This compound is prone to decomposition and therefore we were unable to obtain satisfactory elemental analyses or high resolution MS.

Ethyl 5-formyl-3-methyl-4-isoxazolecarboxylate (16). ${ }^{35}$ A mixture of alcohol $21(0.50 \mathrm{~g}, 2.7$ mmol) and PCC (0.88 g, $4.1 \mathrm{mmol})$ was stirred in $\mathrm{CH}_{2} \mathrm{Cl}_{2}$ for two weeks at room temperature. The reaction mixture was filtered and the precipitated solids washed with $\mathrm{CH}_{2} \mathrm{Cl}_{2}$, the filtrate was isolated and washed successively with water and brine then dried over $\mathrm{MgSO}_{4}$ then concentrated under vacuum. The crude was purified by a short column chromatography (30$100 \%$ petrol:Et $\left.{ }_{2} \mathrm{O}\right)$ to give the aldehyde as a yellow oil $(0.41 \mathrm{~g}, 82 \%) ; \mathrm{IR} v_{\max }$ (neat)/ $\mathrm{cm}^{-1} 1729$, 1705, 1605; ${ }^{1} \mathrm{H}$ NMR $\left(400 \mathrm{MHz}, \mathrm{CDCl}_{3}\right) \delta_{\mathrm{H}} 1.43\left(3 \mathrm{H}, \mathrm{t}, J=7, \mathrm{OCH}_{2} \mathrm{CH}_{3}\right), 2.55\left(3 \mathrm{H}, \mathrm{s}, \mathrm{H}_{3} \mathrm{C}-\right.$ $\mathrm{C}=\mathrm{N}), 4.40\left(2 \mathrm{H}, \mathrm{q}, J=7, \mathrm{OCH}_{2} \mathrm{CH}_{3}\right), 10.35(1 \mathrm{H}, \mathrm{s}, \mathrm{CHO})$. The IR and NMR data are consistent with literature data. ${ }^{35}$

\section{Ethyl 3-methyl-5-((E)-\{[(4-methylphenyl)sulfonyl]hydrazono\} methyl)-4-}

isoxazolecarboxylate (26). To a stirred suspension of $p$-toluenesulfonyl hydrazide (185 $\mathrm{mg}$, $0.993 \mathrm{mmol}$ ) in methanol, at $0{ }^{\circ} \mathrm{C}$, was added the aldehyde 16 (200 mg, $\left.1.09 \mathrm{mmol}\right)$. The resulting solution was stirred for one hour at $0{ }^{\circ} \mathrm{C}$ and then concentrated under vacuum to yield a pale yellow solid. The crude product was purified by recrystallization $\left(\mathrm{MeOH} / \mathrm{Et}_{2} \mathrm{O}\right)$ to give the hydrazone as white needles (230 mg, 66\%); mp 125-126 ${ }^{\circ} \mathrm{C} \quad\left(\mathrm{MeOH} / \mathrm{Et}_{2} \mathrm{O}\right) ; \mathrm{R}_{f} 0.47$ $\left(\mathrm{MeOH} / \mathrm{CH}_{2} \mathrm{Cl}_{2}, 0.1: 9.9\right)$; IR $v_{\max }$ (neat) $/ \mathrm{cm}^{-1} 3193,2987,1690,1614,1559 ;{ }^{1} \mathrm{H}$ NMR (400 $\left.\mathrm{MHz}, \mathrm{CDCl}_{3}\right) \delta_{\mathrm{H}} 1.35\left(3 \mathrm{H}, \mathrm{t}, J=7.3, \mathrm{CO}_{2} \mathrm{CH}_{2} \mathrm{CH}_{3}\right), 2.40\left(3 \mathrm{H}, \mathrm{s}, \mathrm{H}_{3} \mathrm{C}-\mathrm{C}=\mathrm{N}\right), 2.44\left(3 \mathrm{H}, \mathrm{s}, \mathrm{CH}_{3}-\right.$ Ts), 4.32 (2H, q, $\left.J=7.3, \mathrm{CO}_{2} \mathrm{CH}_{2} \mathrm{CH}_{3}\right), 7.30(2 \mathrm{H}, \mathrm{d}, J=8.3$, Ts $), 7.86(2 \mathrm{H}, \mathrm{d}, J=8.3, \mathrm{Ts}), 8.30$ $(1 \mathrm{H}, \mathrm{s}, \mathrm{HC}=\mathrm{NNH}) ;{ }^{13} \mathrm{C}\left(100 \mathrm{MHz}, \mathrm{CDCl}_{3}\right) \delta_{\mathrm{C}} 166.0(\mathrm{~s}), 161.4(\mathrm{~s}), 160.0(\mathrm{~s}), 144.53(\mathrm{~s}), 135.0$ (s), $132.8(\mathrm{~d}), 129.8(\mathrm{~d}, 2 \times \mathrm{C}), 128.0(\mathrm{~d}, 2 \times \mathrm{C}), 111.6(\mathrm{~s}), 61.4(\mathrm{t}), 21.5(\mathrm{q}), 14.0$ (q), $11.6(\mathrm{q})$; MS m/z (CI) 352 ([MH] $\left.]^{+}, 14\right), 196$ (69), 157 (100). Anal. Calcd for: $\mathrm{C}_{15} \mathrm{H}_{17} \mathrm{~N}_{3} \mathrm{O}_{5} \mathrm{~S}$; found $\mathrm{C}$, 51.12; H, 4.54; N, 11.48; required C, 51.27; H, 4.88; N, 11.96 . 


\section{Acknowledgements}

We thank the EPSRC and Syngenta for funding a CASE award.

\section{References}

1. Holzapfel, C. W. Tetrahedron 1968, 24, 2101.

2. Holzapfel, C. W. In The Biosynthesis of Mycotoxins - A Study in Secondary Metabolism; Steyn, P. S., Ed.; Academic Press: New York, 1980.

3. Riley, R. T.; Goeger, D. E.; Yoo, H.; Showker, J. L. Toxicol. Appl. Pharmacol. 1992, 114, 261.

4. Karon, B. S.; Mahaney, J. E.; Thomas, D. D. Biochemistry 1994, 33, 13928.

5. Demaurex, N.; Lew, D. P.; Krause, K. H. J. Biol. Chem. 1992, 267, 2318.

6. Holzapfel, C. W.; Hutchison, R. D.; Wilkins, D. C. Tetrahedron 1970, 26, 5239.

7. Steyn, P. S.; Wessels, P. L. Tetrahedron Lett. 1978, 19, 4707.

8. Kozikowski, A. P.; Greco, M. N.; Springer, J. P. J. Am. Chem. Soc. 1984, 106, 6873.

9. Muratake, H.; Natsume, M. Heterocycles 1985, 23, 1111.

10. Haskins, C. M.; Knight, D. W. Chem. Commun. 2005, 3162.

11. Holzapfel, C. W.; Wilkins, D. C. Phytochemistry 1971, 10, 351.

12. Schabort, J. C.; Wilkins, D. C.; Holzapfel, C. W.; Potgieter, D. J. J.; Neitz, A. W. Biochim. Biophys. Acta 1971, 250, 311.

13. Steyn, P. S.; Vleggaar, R.; Ferreira, N. P.; Kirby, G. W.; Varley, M. J. J. Chem. Soc., Chem. Commun. 1975, 465.

14. De Jesus, A. E.; Steyn, P. S.; Vleggaar, R.; Kirby, G. W.; Varley, M. J.; Ferreira, N. P. J. Chem. Soc., Perkin Trans. 1 1981, 3292.

15. Aggarwal, V. K.; Alonso, E.; Fang, G.; Ferrara, M.; Hynd, G.; Porcelloni, M. Angew. Chem. Int. Ed. 2001, 40, 1433.

16. Aggarwal, V. K.; Vasse, J.-L. Org. Lett. 2003, 5, 3987.

17. Aggarwal, V. K.; Badine, D. M.; Moorthie, V. A. In Aziridines and Epoxides in Organic Synthesis; Yudin, A. K., Ed.; Wiley-VCH: Weinheim, 2006.

18. Ungureanu, I.; Klotz, P.; Schoenfelder, A.; Mann, A. Tetrahedron Lett. 2001, 42, 6087.

19. Ungureanu, I.; Klotz, P.; Mann, A. Angew. Chem. Int. Ed. 2000, 39, 4615.

20. Ungureanu, I.; Bologa, C.; Chayer, S.; Mann, A. Tetrahedron Lett. 1999, 40, 5315.

21. Jones, R. C. F.; Bhalay, G.; Carter, P. A.; Duller, K. A. M.; Dunn, S. H. J. Chem. Soc., Perkin Trans. 1 1999, 765.

22. Baraldi, P. G.; Barco, A.; Benetti, S.; Pollini, G. P.; Simoni, D. Synthesis 1987, 857.

23. Stork, G.; Hagedorn, A. A., III J. Am. Chem. Soc. 1978, 100, 3609.

24. Stork, G.; Danishefsky, S.; Ohashi, M. J. Am. Chem. Soc. 1967, 89, 5459. 
25. Jones, R. C. F.; Bhalay, G.; Carter, P. A.; Duller, K. A. M.; Vulto, S. I. E. J. Chem. Soc., Perkin Trans. 1 1994, 2513.

26. Stork, G.; McMurry, J. E. J. Am. Chem. Soc. 1967, 89, 5461.

27. Natale, N. R.; McKenna, J. I.; Niou, C. S.; Borth, M.; Hope, H. J. Org. Chem. 1985, 50, 5660 .

28. Roy, A. K.; Rajaraman, B.; Batra, S. Tetrahedron 2004, 60, 2301.

29. Letsinger, R. L.; Jamison, J. D. J. Am. Chem. Soc. 1961, 83, 193.

30. Hass, H. B.; Bender, M. L. J. Am. Chem. Soc. 1949, 71, 1767.

31. Henbest, H. B.; Jones, E. R. H.; Walls, I. M. S. J. Chem. Soc. 1950, 3646.

32. MacInnes, I.; Walton, J. C. J. Chem. Soc., Perkin Trans. 2 1987, 1077.

33. Warrener, R. N.; Cain, E. N. Aust. J. Chem. 1971, 24, 785.

34. Gelin, S.; Hartmann, D. J. Heterocycl. Chem. 1976, 13, 521.

35. Chantegrel, B.; Deshayes, C.; Pujol, B.; Zhong, J. J. Heterocycl. Chem. 1990, 27, 927.

36. Deshayes, C.; Chabannet, M.; Gelin, S. Synthesis 1984, 868.

37. Zhang, S.; Marshall, D.; Liebeskind, L. S. J. Org. Chem. 1999, 64, 2796.

38. Aggarwal, V. K.; Bae, I.; Lee, H.-Y.; Richardson, J.; Williams, D. T. Angew. Chem. Int. Ed. 2003, 42, 3274.

39. Yajima, T.; Munakata, K. Chem. Lett. 1977, 891.

40. Aggarwal, V. K.; Thompson, A.; Jones, R. V. H. Tetrahedron Lett. 1994, 35, 8659.

41. Aggarwal, V. K.; Ferrara, M.; O'Brien, C. J.; Thompson, A.; Jones, R. V. H.; Fieldhouse, R. J. Chem. Soc., Perkin Trans. 1 2001, 1635.

42. Pangborn, A. B.; Giardello, M. A.; Grubbs, R. H.; Rosen, R. K.; Timmers, F. J. Organometallics 1996, 15, 1518.

43. Gelin, S.; Chabannet, M. Synthesis 1978, 448.

44. Jones, R. C. F.; Duller, K. A. M.; Vulto, S. I. E. J. Chem. Soc., Perkin Trans. 1 1998, 411. 